\title{
INDIGENOUS TRADITIONAL KNOWLEDGE ( ITK) FROM THE FARMERS OF GONDIA DISTRICT REGARDING USE OF PLANTS AGAINST STORED GRAIN PESTS.
}

\author{
S.B.Juneja (Banerjee) \\ Department of Zoology, Dhote Bandhu Science College, Gondia. \\ E-mail: sb107banerjee@gmail.com
}

Communicated : 21.12.19
Revision : 07.01.2020

Accepted : 26.01.2020
Published: 30.01 .2020

\begin{abstract}
:
Botanicals have been used since time immemorial for protection of stored products against common pests. They acts as repellents, antifeedants, toxicants and behave as natural grain protectants by behaving as chemosterilants/reproduction inhibitors or insect growth and development inhibitors. Identification and utilization of folk indigenous knowledge regarding use of different parts of plants for the protection of stored grain from the elderly people of rural and tribal belts helps in bridging the gap between the current scientific and age-old practices. It can be a useful component of an IPM strategy for stored grain pest management. Hence, surveys of particular regions are of utmost importance in exploring new avenues for research in this field. In this paper, some of the identified important indigenous storage practices adopted by the people of the area have been described. Documentation of the information was done by questionnaire method.
\end{abstract}

Key words: - Indigenous technologies, Storage pests

\section{INTRODUCTION:}

Botanical insecticides have long been touted as to synthetic chemical insecticides for pest management. Chemicals being harmful to the environment, human beings and animals have created many complex environmental problems. Due to tremendous environmental hazards and residual effects of chemicals, an urgent need of searching alternative in plant and plant products has been emphasized. The scientific literature documenting bioactivity of different plant parts and their derivatives are in ample, yet only a handful of botanicals are currently used as grain protectants. Ethano-botanical knowledge of local communities helps to explore new horizons which can be useful for the coming generations to be benefitted. Hence, the present study was carried out with an objective to document the common botanicals used by farmers of Gondia district as grain protectants.

\section{MATERIAL AND METHODS:-}

The present study was conducted throughout the year in and around Gondia City of Maharashtra State of India. Information about the prevalent stored product pest management strategies was collected from farners through direct interviews and questionnaire methods.

\section{RESULT AND DISCUSSION}

Since ancient times, a lot of efforts have been made to protect harvest production against the pests. In many parts of world, locally available plants are currently in use to protect stored products against damage caused by insect infestation (Hassanalli and Lwande, 1989; Tripathi et al., 2009; Khater, 2012). Numerous studies have documented the use of indigenous local herbs and plant materials used worldwide (Cox et al., 1998; Rauha et al., 2000; Ahmad et al., 2001; Penna et al., 2001). Many of these plants are widely used by local communities in traditional medicine for the treatment of several ailments. Leaves, twigs and flowers have been admixed as protectant in different parts of world, particularly India, China and Africa (Golob et al., 1999). The practical advantage of using locally available material to protect stored products destined for household and small scale use remains compelling (Weaver and Subramanyam, 2000). The advantages of insecticide admixture treatments are that they are generally easy to prepare, inexpensive and a single application is 
effective, correctly formulated, give control of existing insect infestation.

Over 450 botanical derivatives are used in traditional agricultural systems in India. The effectiveness of many local plant derivatives against insect pests have been reviewed earlier (Jacobson, 1958, 1975, 1990). The insect repellent and antifeedant properties of Nishinda ( Vitex negundo), Biskatali ( Polygonum serrulatum), Tobacco (Nicotiana tobaccum), Neem (Azadirachta indica), Turmeric (Curcuma longa), Castor (Ricinus communis), Royna (Aphanamix polystachya) have been reported against stored product pests viz. Tribolium castaneum (Jilani and Malik, 1973; Qadri, 1973; Jilani et al., 1988; Parveen and Mondal, 1992). , Rhizopertha dominica (Pereira and Wohlgemuth, 1982), Sitophilus oryzae (Khanam et al., 1991) and Sitotroga cerealella (Abraham et al., 1973). Subsequently a number of workers have also done work with the repellency test of neem seed kernel and extracts of neem against different insect pests ( Nakanishi, 1975; Radwanski, 1977a; Jacobson et al., 1978).

Present studies show that the farmers of this region have been using plant and plant products for biological control of stored grain pests. The plants used belong to 21 families and 24 genera. (Table). Different plants used as grain protectants in Gondia district are enlisted as under.

Most of the plants used as grain protectants have been found to have medicinal properties. The rhizomes of sweet flag (Acorus calamus) are used for numerous medicinal purposes. The herb is used both internally as well as externally. In rheumatism, rheumatic fever and in $\square$ amed joints, the paste applied externally alleviates the pain and swelling. Internally sweet flag is valuable in a vast range of diseases. It is effective for digestive ailments such as flatulence, loss of appetite, abdominal dull pain and worms. The powder of sweet flag given with lukewarm salt-water, induces vomiting and relieves phlegm, while easing coughs and asthma.In epilepsy, the powders of sweet flag, Brahmi and jatamamsi work well, when given with honey. The popular Ayurvedic formulation Sarasvata Choorna, which contains sweet flag, is commonly used to treat epilepsy, hysteria and as a brain tonic. Granule Asabi (Unani preparation) is an excellent nervine tonic which improves memory, reception as well as the speech. As it stimulates the uterine contractions, so it is used to augment the labour pains. It is also salutary in dysmenorrhoeal. (Chaturvedi, A. and Diwanji, B.B. 1995)
The leaves of Annona reticulate, Arachis hypoglea and Azadirachta indica is used for the treatment of high blood pressure,fever, stomach upset and Malaria respectively. Moringa oleifera Leaves are used for the treatment of Asthma, arthritis, rheumatism, and Ulcer, Cymbopogon citrus Lemon Grass Leaves are Antipyretic and used for cold, stomach ache. ( Akande ,2018). Int. J. Innovative Biosciences Res. 6 (1):20-27, 2018.

The essential oil of the leaves called tejpat oil is medicinally used as carminative, anti-flatulent, diuretic, and in cardiac disorders. It is also used in pharma-ceutical preparations because of its hypoglycemic, stimulant and carminative properties. Owing to its high medicinal value and being an important ingredient of the spices, (Sharma \& Nautiyal,2011).

Curcuma longa has been commonly used as a traditional remedy for a variety of symptoms such as inflammation, gastritis and gastric ulcer. One study showed that an ethanol extract from $C$. longa specifically inhibits gastric acid secretion by blocking $\mathrm{H}(2)$ histamine receptors in a competitive manner (Kim 2005).

Linum usitatissimum, commonly known as Flaxseed has traditionally been used for the management of diarrhea and gastrointestinal infections. Pharmacological basis for the medicinal use of Linum usitatissimum (Flaxseed) in infectious and non-infectious diarrhea. (Palla et al., 2015).

\section{CONCLUSION:}

Storage of grains and seeds without pest infestation is essential. Since the plants found in this study are medicinal, they are quite safe for human consumption and thus can be included in stored grain pest control strategy. However, further work aimed at isolation of the specific compounds acting against the insects and nature of the effects of the compounds at the cellular level is recommended.

\section{REFERENCES}

Abraham, C.C.; Allan, T.C. and Calavan, E.C. 1973. Relative efficiency of some plant products in controlling infestation by the Angoumois grain moth, Sitotroga cereallela infesting stored paddy in Kerala. Agril. Res. J. 10 : 59-60.

Ahmad, I. and Beg, A.Z. 2001. Antimicrobial and phytochemical studies on 45 Indian medicinal plants against multi-drug resistant human pathogens. Journal of Ethnopharmacology, 74: 113-123. 
Akande . 2018. Int. J. Innovative Biosciences Res. 6 (1):20-27, 2018.

Chaturvedi, A. and Diwanji, B.B. 1995. Medicinal value of some weed plants of Ratlam District, MP In: Padhye MD, Mukherjee PK and Khalatkar AS (ed) Botany towards 2000 AD Datson's Publishers Nagpur. 139-146.

Cox, S. D., Gustafson, J. E., C. M., Markham, L., Liew, Y. C., Hartland, R. P. Bell, H. C., warmington, J. R., and Wyllie, S.G. 1998. Tea tree oil causes $\mathrm{K}+$ leakage and inhibits respiration in Eshcerchia coli. Letters in Applied Microbiology, 26: 355358.

Golob P. and Gudrups I. 1999. "The use of spices andmedicinals as bioactive protectants for grains," FAO Agricultural Sciences Bulletin 137, FAO, Rome, Italy.

Hassanali, A., Lwande, W., Ole-Sitayo, N., Moreka, L.; Nokoe, S. and Chaya, A. 1990. Weevil Repellent Constituents of Ocimum suave Leaves and Eugenia caryophyllata Cloves Used as Grain Protectants in Parts of East Africa. Discovery and Innovation 2: 91-95.

Jacobson, M. 1958. Insecticide from plants : a Review of literature 1941-53. USDA. Agricultural book, 134.

Jacobson, M. 1975. Insecticide from plants : a review of literature 1954-71. USDA. Agricultural hand book, 461. 102

Jacobson, Reed, D.K., Crystal, M.M and Moreno, D., 1978. Chemistry and biological activity of insect feeding deterrents from certain weed and plants. Exp. Entomol. Appl. 65 : 23-26.

Khanam, L.A.; Khan, A.R. and Talukder, D. 1991. Use of some indigenous plant materials as controlling Sitophilus oryzae infesting wheat. J. Asiatic Soc. Bangladesh 17 (1): 75-78.

Nakanishi, K. 1975. Structure of insect antifeedants, Azadirachtin. Recent Adv. Phytochem. 9 : 283-298.

Palla $\mathrm{AH}^{1}$, Khan $\mathrm{NA}^{1}$, Bashir $\mathrm{S}^{1}$, Ur-Rehman $\mathrm{N}^{2}$, Iqbal $\mathrm{J}{ }^{1}$, Gilani $\mathrm{AH}^{3}$.J Ethnopharmacol. 2015 Feb 3;160:618. doi: 10.1016/j.jep.2014.11.030. Epub 2014 Nov 26.

Parveen, N. and Mondol, K.A.M.S.H. 1992. Behavioral response of Tribolium castaneum to turmeric (Curcuma longa) powder. Univ. J. Zool. Rajshahi Univ. $10: 21-24$.

Penna, C., Marino, S., Vivot, E., Cruanes, M. C., Munoz, J.de D., Cruanes, J., Ferraro, G., Gutkind, G. and Martino,V. 2001. Antimicrobial activity of Argentine plants usedin the treatment of infectious diseases. Isolation of active compounds from Sebastiania brasiliensis. Jour. of Ethnopharmacology, 77: 37-40.

Qadri, S. 1973. Some new indigenous plant repellent for storage pests. Pesticides 7 (2) : 18-19.

Radwansky, S. 1977. Neem tree : Uses and potential uses. World crops and livestock. 29 : 111-306.

Rauha, J.P., Remes, S., Heinonen, M., Hopia, A., Kahkonen, M., Kujala, T., Pihlaja, K., Vuorela, H. and Vuorela, P. 2000. Antimicrobial effects of Finnish plant extracts containing flavonoids and other phenolic compounds. International Journal of Food Microbiology, 56: 3-12.

Sharma\&Nautiyal,2011,https://www.researchg ate.net/publication/267692908_Cinna momum_tamala_A_valuable_tree_of_Hi malayas.

Tripathi, A. K., Upadhyay S., Bhuiyan M., and Bhattacharya P. R. 009. "A review on prospects of essential oils as biopesticides in insect-pest management," Jour. of Pharmocological Phytotheraphy, vol. 1, no. 5, pp. 5263.

Weaver and Subramanyam, B. 2000. Botanicals. In; B. Subramanyam and D. Hagstrum (Eds). Alternatives to Pesticides in Stored Products IPM , Dordrecht, Kluwer Academics Publishers. Pp. 303-320. 


\begin{tabular}{|c|c|c|c|c|}
\hline Botanical name & Vernacular name & Family & $\begin{array}{l}\text { Plant part } \\
\text { used }\end{array}$ & Application \\
\hline Acorus & Sweet flag & Acoraceae & Rhizome & $\begin{array}{l}\text { Dried rhizomes are placed } \\
\text { with cereals and pulses to } \\
\text { protect from Cowpea bruchid, } \\
\text { the Rice weevil,TheKhapra } \\
\text { beetle and some other storage } \\
\text { pests. }\end{array}$ \\
\hline Acacia & Babul & Mimosaceae & Ashes of twigs & $\begin{array}{l}\text { Used to protect sorghum, } \\
\text { paddy and pulses }\end{array}$ \\
\hline Aegle marmelos & Bael & Rutaceae & Leaves & $\begin{array}{l}\text { Dried leaves are layered with } \\
\text { pulses and paddy }\end{array}$ \\
\hline Annona reticulate & Custard apple & Annonaceae & Leaf & $\begin{array}{l}\text { Used to mix with and cover } \\
\text { sorghum. }\end{array}$ \\
\hline Arachis hypogeal & Groundnut & Leguminaceae & Seeds & $\begin{array}{l}\text { Oil found effective against } \\
\text { infestation in beans. }\end{array}$ \\
\hline $\begin{array}{l}\text { Azadirachta } \\
\text { indica }\end{array}$ & Neem & Meliaceae & Leaves & $\begin{array}{l}\text { Used to protect Sorghum, } \\
\text { Paddy and pulses }\end{array}$ \\
\hline Brassica sps. & Sarsoon & Brassicaceae & Seeds & $\begin{array}{l}\text { Oil is found effective against } \\
\text { infestation in cereals. }\end{array}$ \\
\hline $\begin{array}{l}\text { Cinnamomum } \\
\text { tamala }\end{array}$ & $\begin{array}{l}\text { Indian } \\
\text { Cassia(Tejpat) }\end{array}$ & Lauraceae & Leaves & $\begin{array}{l}\text { The whole leaves of this plant } \\
\text { are layered between the beans } \\
\text { and the rice. }\end{array}$ \\
\hline Curcuma longa & Haldi & Zingebaraceae & Rhizome & Powder is used as repellent. \\
\hline $\begin{array}{l}\text { Cymbopogon } \\
\text { citrates }\end{array}$ & Lemon grass & Poaceae & Leaves & Used as repellent \\
\hline Glycine $\max$ & Soyabean & Papilionaceae & Seeds & $\begin{array}{l}5 \mathrm{ml} \text { of oil is effective against } \\
\text { infestation in beans. }\end{array}$ \\
\hline Gossypium sps. & Cotton & Malvaceae & Seeds & $\begin{array}{l}\text { oil is used against infestation } \\
\text { in pulses }\end{array}$ \\
\hline Hyptis sps. & Ran tulsi & Labeateae/Lamiaceae & Leaves & $\begin{array}{l}\text { Dried leaves protect stored } \\
\text { millets. }\end{array}$ \\
\hline $\begin{array}{l}\text { Linum } \\
\text { usitatissimum }\end{array}$ & Linseed & Linaceae & Seeds & $\begin{array}{l}\text { Oil is effective against } \\
\text { infestation in cereals. }\end{array}$ \\
\hline Madhuca indica & $\begin{array}{l}\text { Mahua } \\
\text { (Mahogany) }\end{array}$ & Captoceae & Leaves & $\begin{array}{l}\text { Thick layers are admixed with } \\
\text { millet in earthen ware pots. }\end{array}$ \\
\hline Mangifera indica & Mango & Anacardiaceae & Bark & $\begin{array}{l}\text { Used to } \quad \text { protect } \\
\text { sorghum,paddy and pulses }\end{array}$ \\
\hline Murraya koenigii & Curry patta & Rutaceae & Leaves & $\begin{array}{l}\text { The whole leaves of this plant } \\
\text { are layered between the } \\
\text { cereals and the pulses. }\end{array}$ \\
\hline Ocimum sps. & Tulsi & Lamiaceae & Leaves & $\begin{array}{l}\text { Used as repellent against } \\
\text { stored grain pest. }\end{array}$ \\
\hline Ricinus communis & Castor & Euphorbiaceae & Seeds & $\begin{array}{l}\text { Oil is effective against } \\
\text { infestation in beans and } \\
\text { cereals. }\end{array}$ \\
\hline Sesamiumindicum & Til & Pedaliaceae & Seeds & $\begin{array}{l}\text { Oil is effective against } \\
\text { infestation in beans and } \\
\text { cereals. }\end{array}$ \\
\hline $\begin{array}{l}\text { Syzygium } \\
\text { aromaticum }\end{array}$ & Clove & Myrtaceae & Buds & $\begin{array}{l}\text { Used as repellent against } \\
\text { stored grain pest. }\end{array}$ \\
\hline Tamarind ssps. & Tamarind & Caesalpinaceae & Leaves & $\begin{array}{l}\text { Used to } \quad \text { protect } \\
\text { sorghum,paddy and pulses. }\end{array}$ \\
\hline Trigonella sps. & Fenugreek (Methi) & Paplionaceae & Seeds & Mixed with grains. \\
\hline
\end{tabular}

